\title{
EFFECT OF WORKPLACE SPIRITUALITY ON WORK ENGAGEMENT: MEDIATOR EFFECT OF ALTRUISTIC LOVE
}

DOI: 10.17261/Pressacademia.2019.1066

PAP- V.9-2019(13)-p.61-64

Elif Baykal ${ }^{1}$,

${ }^{1}$ Istanbul Medipol University, Kavacık Campus 34722 Beykoz, Istanbul, Turkey. enarcikara@medipol.edu.tr, ORCID: 0000-0003-4694-523X

To cite this document

Baykal, E., (2019). Effect of workplace spirituality on work engagement: mediator effect of altruistic love. PressAcademia Procedia (PAP), V.9, p.61-64

Permemant link to this document: http://doi.org/10.17261/Pressacademia.2019.1066

Copyright: Published by PressAcademia and limited licenced re-use rights only.

\begin{abstract}
Purpose- In this study, it has been supposed that there will be a positive relationship between workplace spirituality and work engagement and person altruistic love will act as a mediator in this relationship

Methodology- Easy sampling methodology and face to face survey methods has been used in order to collect data for the field research of the study. And the data will be analyzed in SPSS 20.0.

Findings- Results confirmed the positive effect of workplace spirituality on work engagement but altruism of the leader did not acted as a mediator in this relationship.

Conclusion- The study provides a confirmation for the positive effects of workplace spirituality on work engagement.

Keywords: Workplace spirituality, work engagement, altruistic love

JEL Codes: M, M12, M54, L84

\section{INTRODUCTION}

Modern people are exposed to many problems that stems from excessive greed and shortage of love and lack of compassion (Cacioppe, 2000). People are compelled to live in a burdensome atmosphere wherein they are often exhausted from an overload of work and abundance of oppressive responsibilities. That is why, people have started to find it difficult to have an inner balance and peace at their work which resulted in a novel search for balance and integrity in life, a demand for harmony in social groups and peace in the minds of people (Moxley 2000). Hence, a more spiritually oriented humankind occurred after all those radical changes in business atmosphere in 21 st century. Under the overwhelming and burdensome conditions of modern business life individuals started to get bored of highly structured and bureaucratic organizations and they started to search for more flexible and meaningful atmospheres for carrying out their tasks. In fact, chaos experienced by modern employees created the need for more intrinsically motivated, more powerful, more authoritized and more resilient employees that are led by authenticity and intrinsic motivators. The new working habits of modern business life created the required atmosphere for the spiritual journey of contemporary workers. In fact, workplace can be regarded as an important arena for motivating people intrinsically. In employee-friendly and spiritually oriented workplaces people feel more motivated, energetic, hopeful, harmonious and dedicated to their work. Workplace spirituality is an important tool in satisfying the needs of modern employees and it is useful in ensuring many positive organizational outputs including organizational commitment, organizational citizenship behaviors, extra role performance and work engagement etc.
\end{abstract}

\section{WORKPLACE SPIRITUALITY}

According to Fry (2003), the architect of spiritual leadership theory, spirituality, that is, spirituality, is a concept related to the positive characteristics of the human soul, such as love, compassion, patience, tolerance, forgiveness, gratitude, sense of responsibility and harmony that provide happiness to oneself and to the environment. In fact, religion is not necessary for spirituality. Fry (2003) uses spirituality, that is, spirituality, in a broader context than religion. The purpose of spirituality is to make one's life meaningful, to provide his own spiritual salvation, not necessarily through religion.

On the one hand, Workplace spirituality explains the organizational climate wherein individuals and organizations see work as an opportunity, a spiritual path, to develop and contribute to society. It includes values such as care, compassion, support to others, internal integrity and honesty (Narcikara, 2017:51). According to Smith and Rayment (2007) it includes the transfer of owns personal values to the work he is 
responsible for. The main purpose of workplace spirituality; is contributing to one's realization of his/her potential in his/her inner world and developing positive attitudes and positive relations with one' s environment.

Workplace spirituality is a highly personal and philosophical concept which can be regarded as a framework of organizational values promoting transcendence through work processes. It contributes to the sense of connectedness which give way to the feelings of compassion and joy (Giacalone and Jurkiewicz, 2003:13). According to Ashmos and Duchon (2000) in order to be able to talk about workplace spirituality it is very important that the internal worlds of the employees are fed by a meaningful work done in a social context.

\section{ALTRUISTIC LOVE}

Altruism has its roots in the Latin world 'alter' that refers to 'other'. This term concerns the place of the others especially when the other part needs help (Post et al., 2002:3). Altruism can be explained as both a sacrificial link with others and a sacrificial attempt to help others in need (Pavenkov et al., 2015:12). Altruistic behaviors are philanthropic actions aiming to do good deals for the sake of goodness. When a person is altruistic he realizes the fact that others are not independent from him and he is not the center of the world. Hence, altruism refers to self-sacrifice in the aid of others and intimate and sincere care for others (Post et al., 2002:3). In relations to that definition altruistic love refers to reproductive success of others at the expense of one's self and it is also considered as the extent to which altruistic acts are genuine. It is closely related to the care which is a kind of love in response to the other in need (Post et al., 2002:4). In this context love explains benevolence, care and compassion felt for others. Moreover, altruistic love is one of the empirical referents of spiritual leadership so it can be expected that it is also an important antecedent of workplace spirituality and leads to the sense of moral satisfaction that comes from helping others (Ahiauzu and Asawo, 2010:98). That is why, altruistic love experienced for others can the reason underlying the motive for offering help to others (Sprecher and Fehr, 2005:631).

\section{DATA AND METHODOLOGY}

\subsection{Research Model and Hypothesis}

In this study we speculated that in a community if all the members prefer have altruistic for each other, a more harmonious and peaceful environment will occur which may in return increase work engagement levels of employees. That is why we established a model wherein we looked for the possble relationships in the model below. In order to test our research model we have suggested three main hypothesis H1: Workplace spirituality has a positive effect on work engagement

$\mathrm{H}$ 2: Altruism of the leader among has a positive effect on work engagement inclinations of the employees

H3: Altruism of the leader act as a mediator in the relationship between workplace spirituality and work engagement inclinations of the employees.

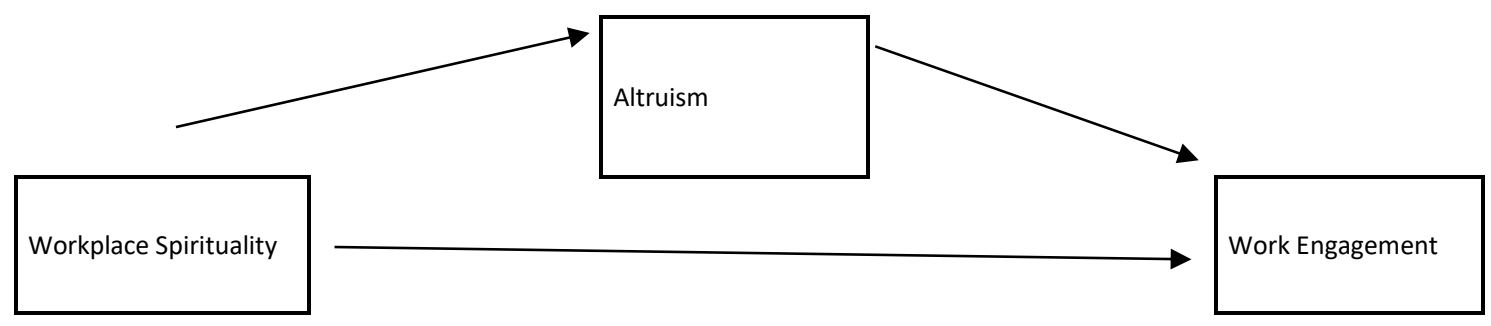

\subsection{Data}

In this study, the questionnaires used in the related field research were conducted with face to face survey method and online survey collection method and the related sample was selected by random sampling method. The sample of the study focused on academicians who are considered to be the most demanding group in terms of workplace spirituality.

The answers of the participants were evaluated with a 5-point Likert Scale. The questionnaires used in the field research of the study consist of three main sections. In the first part, 21-items are borrowed for meaningful work, sense of community and alignment of values from workplace spirituality scale of Afsar and Badir (2017). In the second part, 4 questions are borrowed from Fry's (2003) spiritual leadership scale. And again 8 questions are borrowed for work engagement from Afsar and Badir (2017) workplace spirituality scale.

The survey questionnaire was shared with 800 people, but 190 usable questionnaires were obtained. $52.32 \%$ of the participants in the research had 0-2 years of work experience, $32 \%$ had 2-5 years of experience, $28 \%$ had 5-10 years of work experience and $62 \%$ were male academicians. In the study, factor analysis was used to test whether the observed variables were loaded at the predicted dimensions.

\subsection{Findings}

Kaiser-Meyer-Olkin Sample adequacy analysis was performed to test whether the data in the study sample was sufficient. The sample's adequacy coefficient was 0.921 and the Barlett score was below 0.001 . The relevant values are sufficient to proceed with the analysis of the factor structure. The results of the related factor structures and Cronbach's Alpha values of the factor structures are summarized in Table 1. 
Table 1: Factor Analysis

\begin{tabular}{|c|c|c|c|c|c|c|}
\hline \multicolumn{7}{|c|}{ Structure Matrix } \\
\hline & \multicolumn{5}{|c|}{ Component } & \multirow[t]{2}{*}{ cronbach alfa } \\
\hline & 1 & 2 & 3 & 4 & 5 & \\
\hline SENC28 & 0,851 & & & & & 0.935 \\
\hline SENC29 & 0,847 & & & & & \\
\hline SENC30 & 0,829 & & & & & \\
\hline SENC31 & 0,806 & & & & & \\
\hline SENC26 & 0,798 & & & & & \\
\hline SENC24 & 0,79 & & & & & \\
\hline SENC23 & 0,774 & & & & & \\
\hline SENC27 & 0,767 & & & & & \\
\hline SENC33 & 0,73 & & & & & \\
\hline SENC25 & 0,729 & & & & & \\
\hline SENC32 & 0,617 & & & & & \\
\hline MEANW20 & & 0,864 & & & & 0.815 \\
\hline MEANW19 & & 0,806 & & & & \\
\hline MEANW21 & & 0,782 & & & & \\
\hline MEANW18 & & 0,729 & & & & \\
\hline ALW39 & & & 0,9 & & & 0.794 \\
\hline ALW38 & & & 0,89 & & & \\
\hline WE55 & & & & 0,784 & & 0.722 \\
\hline WE54 & & & & 0,783 & & \\
\hline WE53 & & & & 0,713 & & \\
\hline WE52 & & & & 0,654 & & \\
\hline WE57 & & & & 0,627 & & \\
\hline WE56 & & & & 0,595 & & \\
\hline ALT12 & & & & & 0,906 & 0.899 \\
\hline ALT10 & & & & & 0,889 & \\
\hline ALT11 & & & & & 0,886 & \\
\hline ALT14 & & & & & 0,837 & \\
\hline ALT13 & & & & & 0,687 & \\
\hline
\end{tabular}

Correlation analysis was performed to see whether there is a relationship between sub-dimensions of workplace spirituality (SENC = Society Consciousness, MEAN = Sense of Meaning), WE = Work Engagement and ALT = Altruism dimensions. Correlation results can be seen in Table 2 below. As shown in Table-2, there are significant relationships in each dyadic relationships $\left(\rho^{* *}<0.01, \rho^{*}<0.05\right)$.

Table 2: Correlation Analysis

\begin{tabular}{|l|l|c|c|c|c|c|}
\hline \multicolumn{1}{|l|}{ Correlations } & & MEAN & SENC & ALW & ALT & WE \\
\hline & Pearson Correlation & 1 & & & & \\
\hline MEAN & Pearson Correlation &, $461^{* *}$ & 1 & & & \\
\hline SENC & Pearson Correlation &, $351^{* *}$ &, $310^{* *}$ & 1 & & \\
\hline ALW & Pearson Correlation &, $298^{* *}$ &, $562^{* *}$ &, $233^{* *}$ & 1 & \\
\hline ALT & Pearson Correlation &, $594^{* *}$ &, $489^{* *}$ &, $399^{* *}$ &, $247^{* *}$ & 1 \\
\hline WE &
\end{tabular}

As it is seen in Table 3, we have applied regression analysis in order to test the hypotheses. We had four different regression models. When the results were examined in details, first hypothesis was confirmed, that is to say, workplace spirituality had a statistically significant effect on work engagement (Adjusted R2 : 0,429***, F: 49.614). Similarly H2 was also confirmed (Adjusted R2 : 0,310***, F: 30.059). Hence we can say that workplace spirituality has a positive effect on altruism but only through the subdimension of sense of community. On the other hand, in the third regression model, the relationship between altruism and work engagement has been tested. Results confirmed that the third hypothesis of the study is also valid, thus the positive effect of altruism on work engagement has been confirmed (Adjusted R2 : $\left.0,560^{* * *}, \mathrm{~F}: 12.532\right)$. And lastly, in order to see the avalibility of mediator effect of altruism in the relationship between workplace spirituality and work engagement the fourth regression model has been designed. According to regression results the fourth hypothesis of the study has not been confirmed. Results of the study showed that in the relationship between workplace spirituality and work engagement when altruism is added to the model the effects of subdimensions of workplace spirituality did not disappear or diminish so we can not talk about the mediateor effect of altruism in this relationship. 
Table 3: Regression Analysis

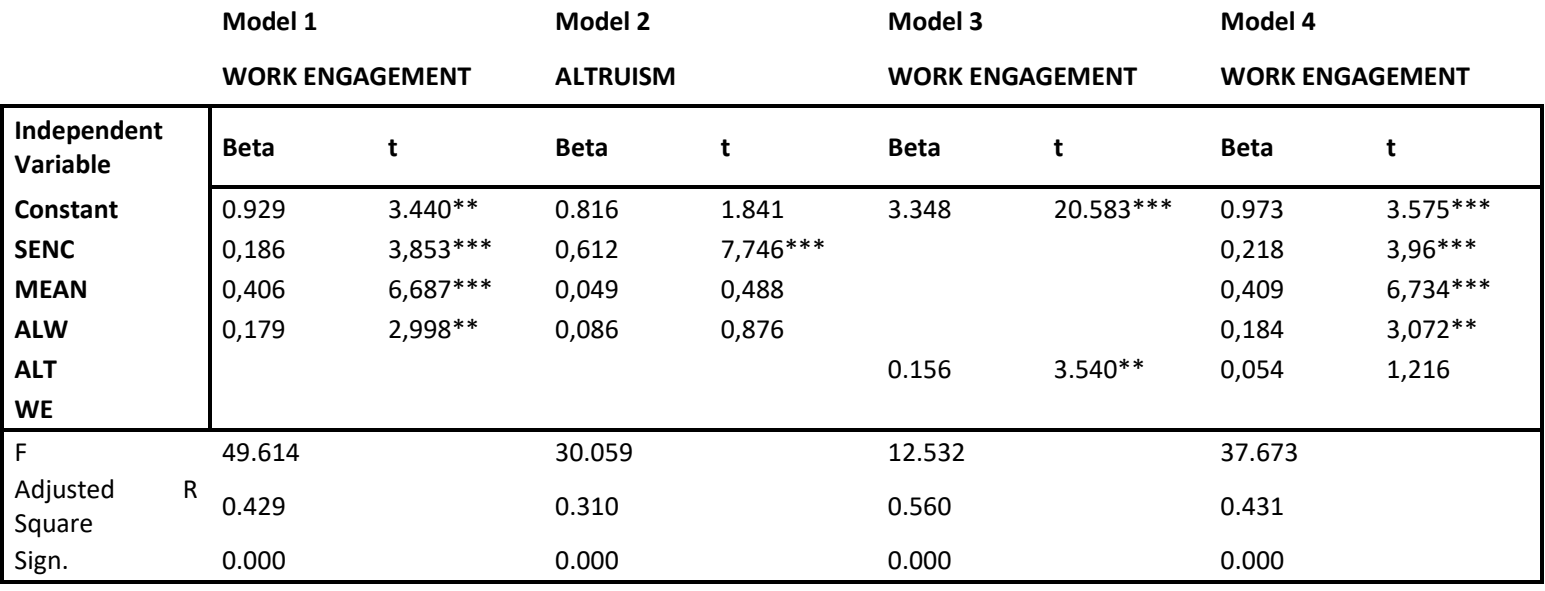

\section{CONCLUSION}

In this study positive relationships have been found in workplace spirituality-altruism relationship and in between workplace spiritualitywork engagement relationship but the assumption that altruism can act as a mediator in the relationship between workplace spirituality and work engagement has turned out to be invalid. From this study we can confer that leaders' Altruistic behaviors do not necessarily shade the positive effects of workplace spirituality on work engagement.

\section{REFERENCES}

Aqlan, F., \& Lam, S. S. (2015). A fuzzy-based integrated framework for supply chain risk assessment. International Journal of Production Economics, 161, 54-63. doi:10.1016/j.ijpe.2014.11.013

Afsar, B., \& Badir, Y. (2017). Workplace spirituality, perceived organizational support and innovative work behavior: The mediating effects of person-organization fit. Journal of workplace Learning, 29(2), 95-109.

Ahiauzu, A., \& Asawo, S. P. (2010). Altruistic love culture and workers' commitment in the Nigerian manufacturing industry: A study in workplace spirituality. Journal of Management Policy and Practice, 11(5), 97-105.

Ashmos, D., \& Duchon, D. (2000). Spirituality at work: A conceptualization and measure. Journal of Management Inquiry, 9(2), $134-145$.

Cacioppe, R. (2000). Creating spirit at work: Re-visioning organization development and leadership-Part I. Leadership \& Organization Development Journal, 21(1), 48-54.

Fry, L. W. (2003). Toward a theory of spiritual leadership. The Leadership Quarterly, 14(6), 693-727.

Giacalone, R., \& Jurkiewicz, C. (2003). Toward a science of workplace spirituality. In R. Giacalone, \& C. Jurkiewicz (Eds.), Handbook of workplace spirituality and organizational performance (pp. 3-28). Armonk, NY7 Sharpe.

Moxley, R. S. (2000). Leadership and spirit. San Francisco, CA: Jossey-Bass.

Narcıkara, E. (2008). Spiritüel Liderlik ve Algılanan Performans Üzerine Etkisi. Yıldız Teknik Üniversitesi/Sosyal Bilimler Enstitüsü, İstanbul.

Pavenkov, O., Pavenkov, V., \& Rubtcova, M. (2015). The altruistic behavior: characteristic of future teachers of inclusive education in Russia. Procedia-Social and Behavioral Sciences, 187, 10-15.

Post, S. G., Underwood, L. G., Schloss, J. P., \& Hurlbut, W. B. (2002). Altruism and altruistic love: Science, philosophy, and religion in dialogue. Oxford University Press.

Smith, J. A., \& Rayment, J. J. (2007). The global SMP fitness framework: A guide for leaders exploring the relevance of spirituality in the workplace. Management Decision, 45(2), 217-234.

Sprecher, S., \& Fehr, B. (2005). Compassionate love for close others and humanity. Journal of Social and Personal Relationships, 22(5), 629651. 